\title{
Towards the Uberisation of Legal Practice ${ }^{1}$
}

\author{
Margaret Thornton ${ }^{2}$ \\ The Australian National University, Canberra, Australia
}

\begin{abstract}
Uber and Airbnb signify new ways of working and doing business by facilitating direct access to providers through new digitalised platforms. The gig economy is also beginning to percolate into legal practice through what is colloquially known as NewLaw. Eschewing plush offices, permanent staff and the rigidity of time billing, NewLaw offers cheaper services to clients to compete more effectively with traditional law firms. For individual lawyers, autonomy, flexibility, a balanced life, well-being and even happiness are the claimed benefits. The downside appears that NewLaw favours senior and experienced lawyers while disproportionately affecting recent graduates. This article draws on interviews with lawyers in Australian and English NewLaw firms to evaluate the pros and cons of NewLaw.
\end{abstract}

Keywords: NewLaw; law; technology; flexible work; gender; age.

“"NewLaw" gives lives back to our lawyers and enables them to design their life as they wish to live it”. ${ }^{3}$

\section{Introduction}

In the late twentieth century, the neoliberal imperative - with its emphasis on cutting costs to maximise profits - saw a general move away from full-time permanent work to casualisation. This trend was boosted by the 'gig economy', which emerged from the global financial crisis of 2008-09. ${ }^{4}$ The gig economy entails the traditional employment relationship being fragmented into 'short term, intermittent work for multiple engagers ("gigs")'. ${ }^{5}$ Tasks are usually performed through digital platforms by individuals as independent contractors. ${ }^{6}$ The ride-sharing service, Uber, which is changing the nature of work, is the best known of these. ${ }^{7}$ While 'gigging' is popularly depicted as the preserve of low-skilled and low-paid workers, white-collar professionals, including lawyers are allegedly the fastest growing sector in the United States (US) ${ }^{8}$ a scenario that is emerging in other parts of the world.

\footnotetext{
${ }^{1}$ Earlier versions of this article were presented as the Liberty Lecture, School of Law, University of Leeds, 30 May 2018 and the Annual Phillipa Weeks Lecture in Labour Law, The Australian National University, 5 December 2018. I thank Hilary Sommerlad, Andrew Francis and Cameron Roles for organising these presentations. I also thank Harry McLaurin for research assistance and the Australian Research Council for financial support (DP120104785).

${ }^{2}$ Emerita Professor of Law, ANU College of Law, The Australian National University, Canberra. ORCID ID 0000-0003-3429-3596.

${ }^{3}$ Cooke, "A New Future for the Law".

${ }^{4}$ Hong, "Making it Work."

${ }^{5}$ Adams, "Rethinking Legal Taxonomies", 475.

${ }^{6}$ Adams, "Rethinking Legal Taxonomies", 477. Consult Todoli-Signes, "The 'Gig Economy", 194.

${ }^{7}$ For a study of Uber in the United States (US) and Canada, see Rosenblat, Uberland.

${ }^{8}$ Mavenlink, "The White-Collar Gig Economy."
}

This work is licensed under a Creative Commons Attribution 4.0 International Licence. As an open access journal, articles are free to use with proper attribution. ISSN: 2652-4074 (Online) 
It appears we are on the cusp of a gig economy in the practice of law, which is reflected in innovative pathways, collectively known as 'NewLaw'. This imprecise descriptor is attributed to Eric Chin, who claims to have coined it as recently as 2013 to describe a business model in which labour arbitrage (taking advantage of a price difference between two or more markets) is used in the delivery of legal services such as 'legal process outsourcing firms, lawyer secondment firms and fixed fees service firms that leverage on demand lawyers'. ${ }^{9}$ In the new entities, referred to variously as firms, platforms or networks, neither physical presence, place nor time are important. The ultimate manifestation of the 'Uber lawyer' is an independent contractor wholly dependent on technological innovation, who chooses what work to do, where to do it and when to do it. ${ }^{10}$

The Australian legal profession led the liberalisation that occurred prior to the global financial crisis as a result of the official adoption of competition policy. ${ }^{11}$ A cluster of reforms emerged, including the incorporation of legal practices ${ }^{12}$ and listing on the stock exchange. ${ }^{13}$ While initially cautious about the reforms, the profession soon embraced them, ${ }^{14}$ tilting the balance away from law as a profession to law as business. ${ }^{15}$ Indeed, the leading law firms apparently emulated their multinational corporate clients in the pursuit of profits when they amalgamated with elite London-based law firms in $2011 .{ }^{16}$

Temporal flexibility dovetailed with the feminisation of labour in the late twentieth century, as women were still expected to take responsibility for caring for children regardless of whether they were in the full-time workforce. ${ }^{17}$ After some years of agitation by women lawyers' associations, law firms accepted flexible work - at least in principle-as they were concerned about the high attrition rate of women lawyers. ${ }^{18}$ However, the acceptance of flexible work coincided with the neoliberal turn that saw a relentless focus on profit maximisation through the key technologies of billable hours and the long-hours culture. In this hypercompetitive milieu, the 'ideal worker', like the 'ideal lawyer' more generally was one who worked full-time and took no time off for childbearing and rearing. ${ }^{19}$

In 2013-14, I investigated the contradictions arising from feminisation and flexible work in a research project entitled 'Balancing Law and Life', focusing on corporate law firms. ${ }^{20}$ The study involved a web-based survey $(n=424)$ and interviews $(n=54)$. The study established that even though most Australian firms endorsed flexible work policies, a stigma attached to those who availed themselves of them. The stigma was most pronounced in the case of male lawyers, despite the policy's claimed gender neutrality. ${ }^{21}$

During the 'Balancing Law and Life' study, it became apparent that NewLaw was highly salient to my project, as it challenged the ways in which legal services were being delivered to clients and the way lawyers lived their lives. ${ }^{22}$ As the academic literature on NewLaw was scant, ${ }^{23}$ I decided to conduct a small study to ascertain the likelihood of dispelling the femininity stigma associated with flexible work in traditional legal practice, as claimed by Williams et al in the US context. ${ }^{24}$

I conducted 30 interviews with lawyers in Australian NewLaw firms in five Australian cities. Although located in four states and territories, the centrality of the Internet means that these firms are not jurisdiction-specific and many have global reach. However, because of the English connections of some of the Australian firms, I conducted another eight interviews in England. The 38 interviews were conducted between March and October 2018. I identified potential interviewees with the assistance of

\footnotetext{
${ }^{9}$ Josef, "Interview with Eric Chin."

10 'Uberisation' may not be strictly accurate as a metaphor because of some of the questionable practices of Uber. However, I felt it encapsulated the novel idea of freedom associated with workers who are able to choose when they work and how much they wish to work, a factor that Uber drivers regard as one of the most important benefits of the job (see Rosenblat, Uberland, 57).

${ }^{11}$ Independent Committee of Inquiry into Competition Policy. The recommendations of the report were incorporated in the Competition Policy Reform Act 1995 (Cth). A similar process of liberalisation also occurred in the United Kingdom (UK). See Legal Services Act 2007 that facilitated a range of 'alternative business structures'.

${ }^{12}$ Mark, "Innovations in Regulation."

${ }^{13}$ Grech, "Slater \& Gordon."

${ }^{14}$ Parker, "Converting the Lawyers", 43.

${ }^{15}$ For example, Bagust, "The Legal Profession."

16 Thornton, "Hypercompetitiveness or a Balanced Life?"

${ }^{17}$ Hardt, Commonwealth. A significant catalyst for reform at the national level was the International Labour Organization Convention 156.

${ }^{18}$ Law Council of Australia, National Attrition and Re-Engagement Study.

${ }^{19}$ Williams, Unbending Gender, 1.

${ }^{20}$ Thornton, "Work/Life or Work/Work?"; Thornton, "The Flexible Cyborg”; Thornton, "Squeezing the Life out of Lawyers".

${ }^{21}$ Compare Williams, Blair-Loy and Berdahl, "Cultural Schemas"; Kay, "Leaving Private Practice".

${ }^{22}$ Cooke, "A New Future for the Law", 15.

${ }^{23}$ An exception is the study conducted by Waye, "Innovation."

${ }^{24}$ Williams, Platt and Lee, "Disruptive Innovation," 5.
} 
websites and law societies, and through the technique known as 'snowballing' in which interviewees recommend other potential interviewees. Ethics approval was obtained from The Australian National University (Ethics Protocol 2017/597) to record and transcribe the interviews. Interviewees were guaranteed anonymity, although some principals would have liked their firm identified, as they were proud of its achievements.

I was particularly interested in why lawyers had left traditional practice, established a new firm or had chosen to become independent contractors, and what working flexibly meant for them, how comfortable they were with the technology and what measures were being undertaken to prevent work from encroaching on their private life. I was also interested in different ways of working, whether as a principal, full-time employee, casual employee or an independent contractor. The issues of flexibility and autonomy were of particular interest, as many interviewees in the Balancing Law and Life project had expressed dissatisfaction with billable hours and the long-hours culture.

Although interest in NewLaw is burgeoning, ${ }^{25}$ law societies do not currently include NewLaw or flexible work practices in their annual surveys. The dearth of statistical data is compounded by the dynamism of NewLaw, with new firms appearing on the scene every week. An English trainer who has been closely involved with trends in legal professionalism believes there had been a 'massive' increase in the proportion of lawyers becoming independent consultants (or contractors). This study of NewLaw represents a preliminary overview that sets out to identify and evaluate its distinctive features.

I have divided the article into two parts: Part I Flexible Capitalism and Part II Uber Lawyering. Part I overviews the key features of NewLaw entities from the perspective of firms, with reference to digitalisation, clientele and costs, while Part II addresses the ramifications of NewLaw for individual lawyers, including the centrality of flexibility and lawyer diversity, with particular regard to gender and age. The study documents the positive experiences of practitioners, particularly women lawyers, with the caveat that the prospects for young lawyers appear less than rosy.

\section{Part I: Flexible Capitalism}

\section{The Definitional Conundrum}

'Disruptive innovation' is the phrase coined by Clayton Christensen to explain how innovation can create new markets or enlarge existing ones. ${ }^{26} \mathrm{He}$ argued that while disrupters normally enter the cheaper end of the market, they can displace traditional firms over time. They introduce simplicity, convenience, accessibility and affordability instead of complexity and high cost. ${ }^{27}$ Christensen pointed out that not all disrupters succeed but their chances of doing so are enhanced by limitations in existing markets. While Christensen's theory has been critiqued, particularly on account of its limited empirical base, ${ }^{28}$ it has applicability to my case study because of the provision of a 'cheaper, complex, more convenient' product in the legal market. NewLaw has been able to establish a foothold because of the high degree of dissatisfaction with billable hours ('an institutionalized disincentive to efficiency') $)^{29}$ and the competitive, hierarchical, rigid and often exploitative ways of working associated with traditional practice that those branching out have sought to slough off:

There were probably three things, essentially. One was time billing and timesheets, which were utterly dysfunctional ... Secondly, it was the business model that law firms operate ... which is competitive, internally competitive, and entirely financially driven ... so we wanted to break away from that to a collaborative collective model, and the third part was just the needless formality and impossibly impenetrable language, and all that sort of stuff that lawyers do to alienate themselves from their clients and everyone else. We wanted to humanise it, open it up, make it more transparent and create an environment where we could be the same people when we are at work as when we're not [Managing Partner, Aus., Male, 8 March 2018].

When I came back after my first baby, I did three days a week ... but the reality was that you worked all the time ... The clincher for me on a day off, I was out walking with my baby ... and I got a phone call asking me why I hadn't returned a call from somebody that day, a really irate phone call saying, 'It was a big client; you should have returned the call'. And I said, 'Well, I didn't know that person called and I'm walking to the shop with my baby on the day that you don't pay me'. So that was the end of that for me ... I met with some like-minded people who said, 'Instead of just working on our own or as a

\footnotetext{
${ }^{25}$ Ryan, "College of Law Boss Opens Up."

${ }^{26}$ Christensen, The Innovator's Dilemma; Christensen, Competing Against Lack.

${ }^{27}$ Christensen, Competing Against Lack, 5.

${ }^{28}$ Lepore, "The Disruption Machine". Consult King, "How Useful is the Theory."

${ }^{29}$ Susskind, Tomorrow's Lawyers, 16.
} 
consultant, we'd like the control of having a brand and having a business, and being a bit more entrepreneurial [Principal, UK, Female, 25 June 2018].

NewLaw principals were anxious to transcend narrow issues of legal regulation and creatively address contemporary problems. Some firms have embraced multidisciplinarity, engaging experts in business, finance, technology, mediation and/or counselling to suit complex problem-solving. One interviewee referred to the personnel considered necessary to address contemporary problems as 'solutionists'. Nevertheless, despite the liberalising reforms of the millennial turn that included multidisciplinary law practices, multidisciplinarity has not taken off to the degree envisaged and most NewLaw firms prefer to operate as incorporated legal practices, primarily engaging lawyers with the assistance of information technology (IT) specialists.

Dispensing with expensive infrastructure, having few permanent staff and relying significantly on the technology, NewLaw has recast legal practice to accommodate openings in the market, including niche specialisations designed to undercut traditional law firms. A restless competitiveness has contributed to the dynamism of NewLaw in which 'faster, better and cheaper' ${ }^{30}$ is the favoured mantra. As a descriptor, NewLaw might best be conceptualised as a blended or hybrid model because of the varying degrees of centralised support it offers in conjunction with flexibility and autonomy:

So, in essence, the firm's model is designed to bring together the best of both worlds, the best of what law firms offer in terms of people, referred work, and back office services and support, melded with the independent decision-making, control, flexibility, and freedom that senior lawyers like to have. In addition, for many lawyers, the choice really is either to leave the firm they're in and go to another firm with a very similar model or to go out into sole practice where they're often isolated without the support and the other limitations that may be associated with sole practice. So, it's a hybrid style of legal practice [CEO, Aus., Male, 8 March 2018].

\section{Digitalisation}

Technology represents the beating heart of NewLaw, which facilitates flexibility through remote working and enables increasingly sophisticated automated platforms, despite the challenge of maintaining relationships with clients in the absence of face-to-face contact:

We're a totally paperless office, so I don't have any filing cabinets in my office. Everything is done online. I get instructions from clients using online forms. I issue documents for signing electronically and then obviously also store documents electronically in a document management system and I have clients that are interstate and overseas and I use videoconferencing and other tools available to me to do that [Principal, Aus., Female, 22 March 2018].

Despite the centrality of technology, the majority of firms rely primarily on email for communication, supplemented by video conferencing, and the cloud for storage rather than expend resources on sophisticated technology. As a conservative profession, law is regarded as resistant to wholesale change ${ }^{31}$ and slower to embrace the new technologies than some would like. ${ }^{32}$ Academic commentary on NewLaw has tended to focus on the effect of artificial intelligence (AI) and the niggling fear that lawyers themselves might become redundant. ${ }^{33}$ However, many recognise the momentum favouring digitalisation is unstoppable. Some firms have a technology arm and work on driving automated workflows, document creation and work triage. The technology enables them to develop bespoke software to improve the efficiency of their corporate clients to suit compliance and workflow processes, ${ }^{34}$ and being able to branch out into technology-based 'start-ups':

We've got ... around eight developers who are in-house just working for [our firm] on our website or in our platforms that we create for clients ... without them, we wouldn't really have a business. We'd be no different to another law firm down the road that has a 100 people. That's what sets us apart, and our marketing as well, and the accessibility of people being able to access that information on our sites and how all that links back in with getting leads into business [HR Manager, Aus., Female, 18 April 2018].

\footnotetext{
${ }^{30}$ Pitcher Partners, "Legal Firm Survey," 4; Waye, "Innovation," 5.

${ }^{31}$ Billett, "The Gig Lawyer."

${ }^{32}$ For example, Susskind, Tomorrow's Lawyers, 10.

${ }^{33}$ Katz, "Quantitative Legal Prediction."

34 Waye, "Innovation," 11.
} 
Sophisticated technology may be costly for a small organisation. One principal who had recently set up her own firm said she could not afford an IT specialist and the cost of specialised software licences was beyond her. This contrasted with the experience of another, who worked from home aided by a team of independent contractors. Her partner was an IT specialist who devised bespoke software to accommodate all aspects of the business, including assigning work to consultants and allowing clients to access their own files. Notably, the large corporate firms likely have a team of legal technologists doing their best to ensure NewLaw does not steal a march on them. ${ }^{35}$ Commentators have documented the ways in which digitalisation is accelerating the economisation and commodification of the practice of law. ${ }^{36}$

\title{
NewLaw Clientele
}

Most NewLaw principals preferred a corporate to an individual clientele, as it was more lucrative. ${ }^{37}$ They frequently set up a new enterprise by bringing their existing clients with them, meaning they could start with a sound financial base:

\begin{abstract}
All the lawyers from the start have brought their own clients and it's fundamental to the model. The remuneration structure in this firm is purely performance based. So it's based entirely on what the firm's collected billings are and the key metric within the firm is 70/30. So the lawyers are earning 70 per cent of the fees that the firm collects in bills for the matters that they work on. And so, in a firm model like ours, if you bring a portable following to the firm, then you'll do very well financially because the firms that people come from tend to pay only around about 30 or so per cent of people's collected billings, whereas in this firm, people are earning 70 per cent. That has the corresponding element that if people don't bring clients to the firm, they're not gonna be able to do very well financially in a firm like ours and so, as a consequence, we only tend to attract experienced lawyers who have a client following [CEO, Aus., Male, 8 March 2018].
\end{abstract}

The NewLaw firms that specialise in responding to the needs of business covered all commercial areas, including corporate finance and regulatory compliance. While distinguishable from corporate law firms in terms of their structure, employment and billing practices, NewLaw firms were anxious to distinguish themselves from recruitment businesses:

\begin{abstract}
There's a key difference between what a recruitment business does and what we do. Basically they have a platform which is a way of connecting people who want a job with clients who need someone to do a job. And so you've gotta be very human about how you do that but ultimately it's just a different stream of people, whereas our business is about building and maintaining the relationships with the lawyers and making them better by being good and being willing to go on the next assignment and so it's always going to be a business. It is about people relationships and so the culture part of it is absolutely crucial to what we do [General Counsel and Company Secretary, Aus., Male, 9 March 2018].
\end{abstract}

There has been a marked increase in in-house lawyering ${ }^{38}$ which has provided opportunities for NewLaw firms. Corporate clients want to make their in-house legal teams more effective by covering absences or upgrading their legal departments. This may involve developing bespoke software to collect and report on organisational data to give corporate clients a better picture of what their lawyers do. It may also involve NewLaw firms sending experienced lawyers to work in-house on secondment for anything from one or two days per week to weeks or months at a time. The firms are more likely to draw on a pool of lawyers who are independent contractors to act as secondees, rather than employees, although this is not always the case. Senior lawyers with experience in both corporate law and in-house practice are preferred, with business experience also being highly regarded. Lawyers on secondment need to be prepared to work on short-term contracts (gigs?) and to enjoy a change of scene:

So basically our business model works with building a team of lawyers who we then place on secondment or assignment with clients so all of our lawyers work from the client's premises as if they were a member of the client's team and sometimes they work more remotely but they're still part of the client's team, working on the client's systems and records [General Counsel and Company Secretary, Aus., Male, 9 March 2018].

The secondment model has also been emulated by large corporate firms that have created dedicated business entities to accommodate the needs of their clients. ${ }^{39}$ BigLaw could no longer ignore NewLaw innovations, thereby endorsing Christiansen's thesis as to the disruptive effect of newcomers on the market. Similarly, the subsidiaries of BigLaw are populated by pools of independent contractors with significant in-house experience and senior law firm experience:

\footnotetext{
${ }^{35}$ Waye, "Innovation," 13, found that larger law firms are more likely engaged in innovation than small firms.

${ }^{36}$ For example, Caserta, "The Legal Profession."

${ }^{37}$ The Australian legal profession is heavily skewed towards servicing corporate clientele, as revealed by the proportion of revenue generated. See Pitcher Partners, "Legal Firm Survey"; Waye, "Innovation," 6.

${ }^{38}$ Mahlab Recruitment, "Mahlab Report".

${ }^{39}$ Waye, "Innovation," 9.
} 
The only lawyers that we'll employ are in-house lawyers. So, we have a view based on feedback from our clients that in-house lawyers operate differently to lawyers who have only worked in a law firm. That's not to say that they're better-they're just different ... they have a much better understanding of how industries or sectors operate and the commercial aspects of whether it's government or a private or public company [Manager, Aus., Male, 5 April 2018].

NewLaw is always on the lookout for gaps in the market that support small and medium-sized businesses in niche areas. Small business start-ups are a particular speciality:

I specialise in start-ups, small business, and franchising. Start-up clients are typically solo operators, probably the first time they've been in business, so there's a bit of handholding there. And then the franchising clients can be franchisees who also might be the first time they've gone into business as well as franchisors, and franchisors can be the more sort of sophisticated corporate clients [Principal, Aus., Female, 22 March 2018].

Once again, taking their cue from NewLaw, some of the large corporate law firms have established subsidiaries specialising in assisting start-ups and emerging companies. Other platforms look to the legal profession itself for new openings:

Like babysitters for law-small law firms and sole practitioners will be able to connect with each other where they need help with overflow work or maybe on a big project or an area that they don't do, or if they wanna take a holiday and they want someone to babysit their practice. So, with that, hopefully that will grow a bit of a community amongst the small law firms and sole practitioners, as big firms have those resources at hand [Principal, Aus., Female, 22 March 2018].

Such developments point to the remarkable agility of NewLaw in responding to perceived gaps in the market.

A range of firms and platforms also cater for everyday issues that affect the lives of individuals, such as conveyancing, divorce, wills and probate in which there is significant unmet need. Neoliberalism may have tarnished the public image of lawyers by tipping the scales towards profit maximisation. ${ }^{40}$ However, a commitment to social justice continues to animate many NewLaw principals, some of whom formerly practised in legal aid and public interest law, but had been compelled to leave because of budget cuts. ${ }^{41}$ They were keen to devise ways of resolving disputes amicably and cheaply without recourse to litigation:

I was concerned with clients complaining about the uncertainty when it came to legal cost and about how frustrating the process was and they were just never happy about what was happening. They also talked about how they felt that the lawyers were not readily accessible, not friendly, would not listen to them, and I thought there is a need in the market for a different approach to the way divorce is done [Family Law Mediator, Aus., Female, 27 March 2018].

The online model suits everyday disputes, as it enables standardised documents to be made available cheaply to consumers. Potential clients pay a fee to be matched with a specialist lawyer online who answers their initial questions, with any further work subject to a fixed-fee arrangement. One interviewee passionate about access to justice for ordinary people described her organisation as a 'legal marketplace'. She hoped low-cost online services would overcome community antipathy towards the profession, and rectify the lack of transparency and uncertainty typical of conventional lawyer-client relations.

\section{The Challenge Of Providing 'More For Less' ${ }^{42}$}

As mentioned, billable hours have been rejected by NewLaw in favour of fixed-price billing, unless the extent of the work is indeterminate as with litigation. Working for a fixed fee was believed to contribute not only to individual well-being but to greater productivity: 'We find lawyers who predominantly work fixed-fee, have better work-life balance and they're more productive and they actually end up being the top billers in the law firm' [Manager, Aus., Female, 22 March 2018].

Minimising the cost to clients is essential for the viability of NewLaw-indeed, it is the only way it can compete successfully with BigLaw in a highly competitive market:

We've got partner level lawyers who are from top tier firms being charged out at the junior lawyer level of [Top Firm]. So you look at the schedule of fees, it's sometimes embarrassing to see that our rate is 10 dollars cheaper than the junior who I'm dealing with at [Top Firm]. I think the paralegals and juniors will probably spend 10 hours on something and my lawyer will

\footnotetext{
${ }^{40}$ Law Council of Australia, The Justice Project.

${ }^{41}$ Law Council of Australia, The Justice Project.

${ }^{42}$ Susskind, Tomorrow's Lawyers, 14.
} 
be charged out at the same rate and they'll spend four hours on it because they're a partner and the client wins [Director, Aus., Female, 3 March 2018].

One director pointed out that avoiding the widespread practice of over-lawyering was an important step taken by her firm to save client costs.

Saving on premises was affected by not spending money on luxurious offices, libraries and expensive artwork. ${ }^{43}$ If lawyers worked on-site, they usually worked in open-plan rather than enclosed offices, often with a hot-desking arrangement or in a coworking space with other businesses. Most significantly, cost-cutting arose from having few permanent staff or relying on inhouse secondments and independent contractors who bore the costs associated with premises, technology and support staff, as well as the risk:

So premises cost goes out the window; support staff cost goes out the window because the clients provide the support for the lawyers, so you're down to 40 per cent of the cost of the law firm less of what we bear, and so we can provide the lawyers at a cost that the clients who don't know us don't expect [General Counsel and Company Secretary, Aus., Male, 9 March 2018].

Technological innovation has contributed significantly to the decline in transaction costs. Legal chat lines and online matching platforms for routine work, for example, entail little cost once established, appealing to individual clients and small business:

So we've made available on our website a suite of 16 documents ... for free, which is quite novel in the legal market, to give away your IP [intellectual property] for free. That's not something that's often done, but anybody can go onto our website and download those documents. And they're updated from time to time in accordance with where the market moves ... the startup landscape has moved in Australia. Over the last few years, it's become much more sophisticated than it was when we first started. And these documents are specifically tailored to start-ups and their needs - and hopefully are user-friendly and plain language English enough that people can pick them up and understand what they are [Co-Head, Aus., Female, 17 April 2018].

Nevertheless, some lawyers were critical of the cheap and ready access to legal documents online, as they created problems for users insufficiently aware of the pitfalls:

\begin{abstract}
We're finding that the experience that clients have with those services isn't necessarily great. So, we have been brought in to fix issues where they've gone wrong because people have chosen one of these online documents. There's very little face-toface contact, if any, with a real lawyer, and these sorts of package documents where they say, 'You can have two hours with a lawyer and this document for a fixed price'. It sounds very attractive and it is very attractive. But I know from experience cos I'm doing a [shareholders] agreement, you cannot do it in two hours. It's something that I think it sort of rolls over a course of a few weeks where you really get to understand that particular client, their particular circumstances, the individuals involved, and you sort of realise that you have to put a lot of effort into it to get it right [Director, Aus., Male, 8 March 2018].
\end{abstract}

If costs are not kept low with simple, reliable and convenient online templates, NewLaw will fail. As Christiansen pointed out, the mortality rate for disruptive technologies is high. ${ }^{44}$ The downside of the effort to keep costs low meant increased effort had to be devoted to attracting work for a business to be viable: 'You're constantly marketing, constantly out there trying to get new work' [Principal, Aus., Female, 19 March 2018].

Marketing was a challenge for a small firm, as a dedicated product manager was expensive. Larger firms were able to afford a marketing department and invested significantly in digital marketing strategies. One firm used blogs, hoping they would be picked up by the mainstream media, while another claimed to have posted more than 8,000 articles on its website. As a 'tech business that provides legal services, rather than a law firm that uses technology to deliver legal services' [HR Manager, Aust, Female, 18 April 2018], the firm's legal team was happy to engage in business development, which lawyers in traditional firms find unappealing.

\footnotetext{
${ }^{43}$ Consult Williams, "Disruptive Innovation," 9, 14.

${ }^{44}$ Christensen, The Innovator's Dilemma, 261.
} 


\section{Part II: Uber Lawyering}

\section{Independent And Autonomous}

The independent contractor is the paradigmatic 'Uberised' worker, who chooses when and where to work. While contractors normally take responsibility for all costs and the quality of the work undertaken, they do not have to tout for business, advertise or come to the office:

If you're a consultant solicitor, you can either work for a virtual firm so that they handle all the back office stuff and you get a percentage, or you work for a real firm with bricks and mortar ... with potential for becoming an owner of that business. If you are a sole practitioner, you bear the responsibility of compliance, which is significant [Consultant and Trainer, UK, Female, 28 June 2018].

While some NewLaw firms rely entirely on contractors, others maintain a core of full-time or casual employees, merely 'filling the gaps' with contractors, some of whom could be sole practitioners with a few clients of their own. ${ }^{45}$ Uber lawyers are in control of their destiny - at least theoretically. The reputation of an independent contractor is all-important, and it was inevitable TripAdvisor-type websites publicly rating a lawyer's performance would eventually make an appearance. ${ }^{46}$ Arguably, peer review empowers the client but a bad review can drive a provider out of the market altogether. ${ }^{47}$

The significant degree of autonomy exercised by independent contractors means NewLaw firms face a challenge in controlling the brand, compelling principals to be particular about who they engage. ${ }^{48}$ They prefer senior and experienced lawyers who can work independently without the need for constant oversight, favouring those whom they either know or have had recommended to them. Collegiality, trust and loyalty are characteristics desired by all employers, but are crucial for lawyers working virtually:

The arrangement I have with X couldn't happen with someone that I hired next week. That is unique, I think, to the fact that we have worked together for so long, we know each other so well, I trust her implicitly. She understands what I'm trying to get done. If I hire someone next week, I certainly wouldn't say, 'Right, you can work from [beachside town in another State], have a good time and let me know how that goes in six months [Principal, Aus., Female, 9 October 2018].

Some principals decline to engage contractors because they feel they cannot satisfy the element of trust:

My experience is that they don't always sing along to the same hymn sheet and because we operate to such a high standard in terms of technical expertise, we like to see people who are trained up to our standards and share our vision and I don't think you can do that unless you actually have people who are employees [Principal, UK, Female,20 June 2018].

NewLaw offshoots of top-tier corporate firms engaged in conventional homosocial hiring practices prefer lawyers with a minimum of two to four years' experience in elite private practice. Some firms with a corporate clientele specify at least 10 years post-qualification experience $(\mathrm{PQE})$ as the threshold.

An element of egalitarianism distinguished the typical NewLaw entity from its traditional corporate firm counterpart. Ambitious and aggressively competitive lawyers did not appeal: 'We're not interested in people who are going to try and clamber over their colleagues to climb the corporate ladder' [Managing Partner, Aus., Male, 8 March 2018]. Even the term 'partner' was sometimes rejected as too hierarchical, being replaced with 'practice leader'. However, in some UK firms all consultants (even if several hundred of them) were designated 'partners' to convey a sense of status and authority:

So, on all of the literature, on my business cards, my email, I am called a partner. So, customers are dealing with services, they're used to seeing the word 'Partner' so effectively just for marketing purposes that's what I'm referred to ... In reality, I formed a separate consultancy company. I'm an independent consultant, so I'm not entitled to paternity leave, or holiday or sick pay, or anything like that [Independent Consultant, UK, Male, 28 June 2018].

In keeping with the philosophy of flexibility and egalitarianism, NewLaw did not have lockstep promotion. If promotion were available, it was merit based. NewLaw employees were assessed on their contributions across a range of areas, including

\footnotetext{
${ }^{45}$ A rise in the number of individuals combining employment with self-employment has been noted as a feature of the gig economy. See Adams, "Rethinking Legal Taxonomies," 478.

${ }^{46}$ For example, Rated Solicitors.

${ }^{47}$ Nurvala, " "Uberisation."”

${ }^{48}$ Consult Williams "Disruptive Innovation," 50.
} 
technical service delivery, product development, business development and marketing, although an informal planning meeting tended to replace the full-scale performance review. If a bonus were paid, it was usually firm wide and based on the firm's overall financial performance; individual bonuses were viewed as unduly competitive and led to dysfunctional behaviour. If competition were played down, lawyers were more likely to refer work to each other, thereby contributing to a sense of cohesion and loyalty.

Apart from the flexibility it affords and the minimal outlay. one might question why contracting might be preferred over establishing one's own firm:

I considered that, but I think the work that I do is very corporate-driven and my work often has lots of other nuances to it that I don't have the expertise for, such as I'm not a litigator. I need litigators and I wouldn't want to be going to a high street firm. I want to be with a corporate large-scale national and international firm [Independent Consultant, UK, Female, 18 June 2018 ].

A major challenge for a law firm in using independent contractors was ensuring they identified with the firm and were distinguished from disaffected workers in the gig economy. Monthly coffee mornings were one way of maintaining a sense of belonging between contractors. Some of the larger firms had a budget for keeping their lawyers 'feeling loved and happy' through regular social events. Others believed a close working relationship between staff was possible only if numbers remained small.

Without observing NewLaw through rose-coloured glasses, it would appear turning away from the corporatisation and commercialism that has animated the large firms since the millennial turn has made a substantial difference to lawyer wellbeing. The amity between lawyers extended to relations with their corporate clients. Word-of-mouth referrals gave rise to good personal and institutional relationships — even 'actual affection' for clients was mentioned — but, more pragmatically, the view was that 'happy clients always get you more clients' [Managing Partner, Aus., Male, 8 March 2018].

\section{Flexibility And Choice}

Flexibility is a central trope of NewLaw that has two distinct meanings. On the one hand, it refers to an employer's ability to adapt and change staffing numbers according to the needs of service delivery. Conversely, flexibility refers to the manner in which individual lawyers work. In the first instance, as a cost-saving mechanism, flexibility emerged as a tool of neoliberal management to avoid the rigidities of Fordism and save costs. ${ }^{49}$ The adoption of 'light capitalism' ${ }^{50}$ thereby enabled the primary labour market to be supplemented or reduced as required. This included portable technology, which has resulted in the economy colonising new sites, predominantly the private sphere, an issue on which I have elaborated elsewhere. ${ }^{51}$ While we need to be wary of the way neoliberals transfer managerial concepts to the social sphere, ${ }^{52}$ it was nevertheless hoped the flexibility for which women lawyers had long campaigned ${ }^{53}$ would facilitate the reconciliation of the demands of work and family.

Through the phenomenon of Uberisation, we observe how the two strands of flexibility have become entwined in NewLaw. On the one hand, it enables law firms to have recourse to well-qualified lawyers without being encumbered by the cost of a permanent workforce. Conversely, individual lawyers are able to achieve a balanced life by combining work with family responsibilities, spending time with friends or pursuing other interests. ${ }^{54}$ Indeed, numerous writers, such as Hannah Arendt, have long recognised that a protected sphere away from the harsh glare of public activity is essential to enable regeneration to occur. ${ }^{55}$ Without that respite, stress, anxiety and depression are inevitable.

Multiple models fall under the rubric of flexible work. Some NewLaw firms employ a core of permanent staff, some rely entirely on contractors, while others use a combination of models:

So we've got two employment models. We've got permanent staff, and we've got casual staff. And the casual staff ... accommodates people being able to work as they want to work and when they want to work; we've got so many different

\footnotetext{
49 Harvey, The Condition of Postmodernity, 147.

${ }^{50}$ Bauman, Liquid Modernity, 54, 57-9.

51 Thornton, "The Flexible Cyborg."

52 Graceffa, "Reinventing the World of Work."

${ }^{53}$ For example, Victorian Women Lawyers, A $360^{\circ}$ Review; Kaufmann, Flexible Partnership.

53 Harvey, The Condition of Postmodernity, 147.

${ }^{54}$ Reiter, "Work Life Balance," 289.

55 Arendt, The Human Condition, 7.
} 
variations or permutations. We have some people who work school hours; we have some people that do two, or three, or four days a week. We've got some people who work full-time and then take ... the next three months off. Some people would take nine, 10,11, 12 months off because they feel like that's what they want to do ... We have an understanding of what the time commitment is for the various roles in those projects and we just send it out to everyone in the team and say, 'Who's interested in this?' and once someone's committed to that project then they're obviously going to make themselves available for the hours that they said they would. So if someone says, 'Oh yep, I could take on that role', and that's a full-time role for the next six months broadly then that's what they'll do and then the next role comes along, they might say, 'Oh no, I don't want to do that again ... I'm going to take the next two months off'. Then when the next project comes along, 'I want to work three or four days'. So ultimately, our only expectation is that people are working for the period they essentially committed to work to meet the client's expectations on a project [Manager, Aus., Male, 2 March 2018].

Casual lawyers might work as much as 2,000 hours per year, the same as permanent staff, but receive a higher income because of their entitlement to annual leave and sick leave loadings. As one male manager said, working flexibly does not mean working less but working differently, with the lawyer being able to choose the hours and place of work without any adverse effect on clients.

Another manager who employed both permanent and casual staff engaged lawyers on contract occasionally, but felt the model was too individualistic and ran counter to building a sound workplace culture. There was also concern a contractor might contract with one firm for one job and with others for additional jobs so that 'they're here, there and everywhere'. The model typifies the gig economy, but points to potential conflict of interest issues for lawyers. One firm with about 200 lawyers and contractors on its books had only 50 or 60 working at any one time but maintained a permanent base of another 40 people to provide a career path for younger lawyers. A balance between permanent and non-permanent workers was intended to give the firm both the reliability and flexibility it desired.

In conventional corporate law firms, a residual suspicion of working away from the office lingers on and remains stigmatised because of its feminised association with caring for young children and the stereotypical assumption of divided loyalties. So entrenched is the norm of 'presenteeism' in traditional legal practice that those who deviate from it may be beset with guilt. The attitude towards working flexibly was different in NewLaw in which some lawyers normally did not come into the firm's office at all. In any case, 'presenteeism' was not feasible for independent contractors who worked in a different city or even a different country. The flexibility of NewLaw was regarded as an ideal solution to accommodating the vagaries of the school day for lawyers with parental responsibilities:

Everybody's now used to just getting online services. And I've got two [contractors] at [place] who're never in the city, but they do fantastic financial services and corporate work for us and they have incredible lives at [place]—beach-walking and yoga and then a little bit of work in the middle $<$ laughs $>$. Wonderful! ... 'I will commit, but not contractually, to trying to give you 10 hours per week and, during school holidays, you don't have to work' ... But during school term, she's got these hours free, so, that's the ultimate in flexibility for her that she probably wouldn't get that anywhere-13 weeks off a year, but then 10 to 15 hours per school term [Director, Aus., Female, 3 March 2018].

I am full-time and I tend to do most of my work when [the children] have gone to bed. So my day is extremely long, but I have chosen that ... So, flexibility means I can work when I want to — but it's typically whenever I've got the chance-you couldn't do that anywhere else [Independent Contractor, UK, Female, 18 June 2018].

It 'takes a huge leap of faith' for women to leave a permanent position and set up their own firm or become an independent contractor. However, those who had established their own firms were proud of what they had done, which included winning prizes for gender diversity and innovative client service. Women with young children who worked as independent contractors felt privileged they had the opportunity to keep on working without a break in their career: 'I don't think I would have taken the leap if I hadn't had children ... but of those that have done it, I don't know of anybody that has said they would go back to work in a traditional way' [Independent Consultant, UK, Female, 18 June 2018].

Work-life balance in the context of NewLaw is not necessarily conceptualised solely in terms of family responsibilities, but favours a more holistic understanding: 'The first principle we stand for is that life comes first and work comes after that' [State Manager, Aus., Female, 7 March 2018]. Such a 'principle' has traditionally been accorded short shrift by corporate law firms, contributing to the exodus of lawyers seeking new ways of working:

They are tired; they are worn out ... there are occasions where I've met people who had health issues, have been in relationship breakdowns; at the other end of the spectrum, people who would like to be in a relationship but haven't had time to spend time 
fostering one. So, there're a lot of reasons lawyers come to consulting. And in the early days, we spend a long time talking to them about what it is that would make them happy <laughs> [Head, Aust., Female, 16 April 2018].

Millennials in particular are said to hold a negative opinion about spending long hours in the office, stressing the need to develop an identity outside the office. ${ }^{56}$

'Being happy' was repeatedly emphasised by interviewees, a state rarely heard in the context of life in a traditional corporate law firm: 'Our lawyers tend to have a passion outside law, which contractualism allowed them to satisfy' [Head, Aus., Female, 16 April 2018]. Writing fiction, studying, teaching, community volunteering, playing sport, pursuing a spiritual path and caring for pets were examples of the diverse interests that had little to do with legal practice but were viewed as desirable to keep lawyers 'fresh and passionate about their work'.

As Gregg observed, work-life balance is not a problem if work is pleasurable-it is only a problem if it cannot be balanced against home, family and leisure time. ${ }^{57}$ A national survey of 4,500 workers in the US revealed that flexibility exerted a greater effect on worker satisfaction and happiness than total number of hours worked or income secured ${ }^{58}$ Contrary to the predatory economy associated with Uber ride-sharing, the 'Uber' lawyers I interviewed evinced a high level of satisfaction with their working conditions because of the exceptional degree of autonomy and control they were able to exercise. However, lawyers needed to be reasonably financially secure to minimise their hours of work:

My guess is 90 per cent of people want certainty, whether that's part-time or full-time, or five hours a week, or ten hours a week ... so they know they can pay their bills. So, what we find quite difficult is that most of the people that apply to work with [X Firm] would like a permanent job, whether that's part-time or full-time [Manager, Aus., Male, 5 April 2018].

While the uncertainty associated with contract work does not suit junior staff or support staff who need income security, flexibility in general is appealing to all workers:

\begin{abstract}
Typically, I work from home every day except for Tuesdays and Thursdays just to give myself and my paralegal certainty that those are our office days, but we're very flexible in that if I've got meetings out and about on one day, I'll just message him and say, 'Do you want to work from home today?' He's done the same as well and said, 'Can I work from home today and then come in to the office tomorrow?' ... I don't mind where we're located as long as we're getting reasonably frequent faceto-face times that I can train him and supervise him and help develop him ... And my practice manager, she works wholly remotely and then we have one day a month where she'll come in [Principal, Aus., Female, 22 March 2018].
\end{abstract}

The long-hours culture in traditional firms has undoubtedly contributed to the stress and depression experienced by lawyers. ${ }^{59}$ As Richard Collier compellingly demonstrated, the high incidence of stress has caused the issue of well-being in the legal profession to move to centre stage across jurisdictions. ${ }^{60}$ The evidence suggests that disempowerment is an integral contributor to depression, stress and anxiety, while the exercise of autonomy and control over one's work is a direct contributor to wellbeing. ${ }^{61}$

Flexible work, choice and autonomy over when to work and when to take time off has contributed to the 'enjoyable experience' of working in NewLaw. ${ }^{62}$ Lawyers working in NewLaw are regarded as more 'rounded' than those in traditional firms as a result of not being obsessed with billable hours and constant surveillance that often results in uncivil behaviours. ${ }^{63}$

\title{
Sex Plus Age
}

It was initially thought NewLaw would be sought mainly by women, but NewLaw is attractive to all lawyers, including former partners in traditional firms who remain disproportionately male. Although mandatory retirement is contrary to age

\footnotetext{
${ }^{56}$ Consult Jacobowitz, "Cultural Evolution."

${ }^{57}$ Gregg, Work's Intimacy, 5.

${ }^{58}$ Golden, "Work Schedule Flexibility."

${ }^{59}$ For example, Chan, "Lawyering Stress"; Bergin, “Australian Lawyer Well-Being”; Omari, "Shut up and Bill."

${ }^{60}$ Collier, "Anxiety and Wellbeing Amongst Junior Lawyers"; Collier, "Wellbeing in the Legal Profession"; Collier, "Love Law, Love

Life", 206. The high incidence of stress and depression has induced law societies to initiate strategies on improving wellbeing. For example, see NSW Young Lawyers, "Being Well in the Law."

${ }^{61}$ Davies, The Happiness Industry, 250.

${ }^{62}$ For example, Baron, "The Elephant in the Room?"; Bagust, "The Culture of Bullying"; Le Mire, "A Propitious Moment?"

${ }^{63}$ For example, Baron, "The Elephant in the Room?"; Bagust, "The Culture of Bullying"; Le Mire, "A Propitious Moment?"
} 
discrimination legislation, ${ }^{64}$ senior lawyers may no longer wish to continue working 24/7 but are not yet ready for retirement. Hence, establishing a NewLaw entity or working as an independent contractor affords them a new lease of life that is both remunerative and satisfying:

I found that the investment bankers I was dealing with were the same age as my children and I'm not someone who likes to be told what to do by my children, so I figured there had to be a better way to do this. I thought well maybe the thing to do is to try and go and work with the clients in-house on the transaction and provide the resources that I had on an in-house basis [General Counsel and Company Secretary, Aus., Male, 9 March 2018].

Given senior men such as this respondent embraced NewLaw and established a firm in which multiple lawyers worked flexibly hints at the dissolution of the feminised stigma associated with flexible work lingering in traditional firms.

The flexibility of NewLaw is nevertheless particularly appealing to women whom society continues to assign responsibility for the primary care of young children. Therefore, it remains a moot point whether NewLaw will attract the seeds of invidiousness conventionally associated with what are considered feminised enclaves. Barzilay and Ben-David, in a study of gender involving 4,600 'online taskers' in the US gig economy, found that women fared less well than men, earning only 37 per cent of the male rate. ${ }^{65}$ They argued that the gig economy is remaking women into devalued workers. Significantly, Barzilay and Ben-David found the most pervasive pay gaps related to those offering legal services. ${ }^{66}$ They suggested that while freelancing superficially appears a 'positive force for women's empowerment and equality', ${ }^{67}$ it contains hidden drawbacks.

As Barzilay and Ben-David's study was limited to hourly rates in platform-facilitated labour in the US, one cannot extrapolate from that study to other jurisdictions. This is because many lawyers who are independent contractors are usually not paid by the hour and, even in the case of those who are, their rates are not publicly available. However, the findings of Barzilay and Ben-David should not surprise us given the historic undervaluation of work undertaken by women. Bolton and Muzio, for example, argued a decade ago that the feminisation of the base of the solicitor's profession enabled male elites to extract an increasing share of surplus labour from women. ${ }^{68}$ This scenario is inferentially supported by data compiled by the Law Society of New South Wales that showed that 75.3 per cent of female private practitioners were employees compared to 59.3 per cent of the profession as a whole. ${ }^{69}$

Although flexibility practices appear less overtly feminised in NewLaw than in traditional legal practice, one cannot automatically conclude that gender equality in the legal profession is about to be realised. Indeed, the need for flexibility by women with parental responsibilities can render them vulnerable, inducing one interviewee to establish her own firm with the intention of assisting other women:

I did get a sense that sometimes working mums could be taken advantage of because of our situation. We can't work full-time in an office. We want to keep our feet in the industry, but then that naturally opens us up to a bit of vulnerability. I know of other working mums that face a real problem of, 'I have to work in this flexible arrangement and take this work because I haven't got any other option at the moment' ... So, I wanted to create something that was really supportive, truly supportive of mums in that position [Principal/Director, Aus., Female, 26 September 2018].

While senior women were able to establish their own firms, authoritative positions in the larger NewLaw firms remained dominated by men. One young woman who left a conservative firm because of its sexism and ageism was disappointed to find that the NewLaw firm she joined was, similarly, male-dominated:

I'm quite a young lawyer - I was admitted very young, and so, even though I had a few years' experience by that time ... I got compared to people's daughters a lot, which was always a bit of a struggle ... So I think it was-yeah, sexism and ageism ... I just felt like it was gonna take another kind of 10 to 15 years until I looked older, sounded older, before I was gonna be able to get my own clients and get my own files and really kind of take responsibility So, I thought that moving to a NewLaw firm with younger, more open-minded clientele would mean that I'd get to kind of have those opportunities a lot sooner than what it looked like I was going to have to wait for ... but all of our senior lawyers and all of our management team are male, all

\footnotetext{
${ }^{64}$ Equality Act 2010 (UK); Age Discrimination Act 2004 (Cth).

${ }^{65}$ Barzilay, "Platform Inequality."

${ }^{66}$ Barzilay, "Platform Inequality," 398.

${ }^{67}$ Barzilay, "Platform Inequality," 401.

${ }^{68}$ Bolton "Can't Live with 'Em," 60. Compare Thornton, "The Flexible Cyborg," 17.

${ }^{69}$ Gender statistics drawn from the NSW Law Society's Annual Report. See Urbis, National Profile.
} 
around 30, I think ... A lot of the other firms that we refer to or work with are also all male-dominated [Employed Lawyer, Aus., Female, 25 September 2018].

While young lawyers are thought to be attracted to the youthism and technological buzz associated with trendy start-ups, the preference for senior lawyers evinced by NewLaw presents a problem for generational renewal given the explosion in the number of recent law graduates ${ }^{70}$ the majority of whom are female. ${ }^{71}$ Consequently, it would appear that NewLaw structurally discriminates against young lawyers on the grounds of sex as well as age. Some firms expressed regret that they could not afford to take on young lawyers and train them, a responsibility they assumed would be undertaken by the traditional firms:

\begin{abstract}
Obviously, we can't send a recently qualified lawyer in to hit the ground running on a short-term stint. We don't have time or the appetite to train a lawyer - that's fine. We want them to come to us when they've had that training ... we do have in our [place] office one recent graduate who had done her PLT [practical legal training] with us and we've employed her, and it's obviously a significant supervision overhead with having a junior lawyer, and as our business grows, we'll be able to do that more and it's something we definitely want to do. But I guess at least for a little while, there's probably gonna be limited opportunities for junior lawyers to do a lot of the work - certainly most of the secondment work [State Manager, Aus., Female, 25 September 2018].
\end{abstract}

Although some NewLaw principals took training seriously and strongly believed junior staff should be in the office to be supervised by more senior staff, generational renewal was usually the responsibility of traditional law firms. Nevertheless, a few NewLaw firms accommodated some recent graduates, albeit in comparatively lowly roles.

Some firms without a large corporate clientele evinced a preference for junior lawyers to undertake a 'specific predefined activity' in the gig economy. ${ }^{72}$ Occasionally, in-house corporate clients asked for paralegals because they were cheaper. Recent graduates and paralegals may work remotely as independent contractors and call in a couple of days per week, while large corporate firms with a NewLaw subsidiary may second junior lawyers and paralegals to their start-up clients to carry out routine work. The absence of a base salary and incidentals, such as holiday pay and sick leave, may suit students in the short-term, but the absence of thoroughgoing training renders them vulnerable.

Millennials (those born between 1980 and the early 2000s) may not be prepared to tolerate the discriminatory treatment indefinitely, particularly when they are about to comprise a substantial proportion of the workforce. ${ }^{73}$ Notably, in the 2017 Urbis Australian national profile of solicitors, the youngest age cohort (24 or younger) decreased by 14.9 per cent between 2014 and 2016, the strongest decrease compared to other age brackets. ${ }^{74}$ This figure is cause for alarm given the ever-increasing numbers of law graduates. The challenge regarding NewLaw is that most firms do not reward supervising others and those who expend time on supervision may be perceived as diminishing their firm's return or their own income:

\begin{abstract}
If for example, I was running my own practice, independent of the current relationship that I have, I probably wouldn't take on anyone - ever. I would just work independently because that gives me complete freedom, and if I have too much work, I'll just refer it to my contacts. That works well for me because I'm not trying to build a business; I'm not trying to make more money. If I was trying to build a practice and really get things rolling then I'd probably enjoy that process because I've had juniors in this context before, and also in the community legal centre, I always had at least three under me and university students volunteering and that sort of thing. I like supervision but it's very difficult when I have such minimal time and it takes three years to add value in this - three years of good commercial law mentoring to be able to start being profitable. I can't afford three years of wages; it doesn't make sense [Employed Lawyer, Aus., Male, 24 September 2018].
\end{abstract}

In contradistinction to the preference for Benchmark Men (i.e., white, Anglo-Celtic, able-bodied, heterosexual, middle-class and middle-aged) still evinced by traditional firms, NewLaw firms proudly claim to seek a more diverse workforce that conveys an up-to-date image:

Something that's really important to me when we're hiring, is not hiring people who are all the same as each other. That's very important to me, around not discounting people based on what uni they went to or what school they went to. For me, it's more

\footnotetext{
${ }^{70}$ A 2015 study revealed that 7,583 students graduated with a basic law degree (an LLB or a JD). See Council of Australian Law Deans, "Data Regarding Law School."

${ }^{71}$ For example, Urbis, National Profile.

72 Consult Tidoli-Signes, 'The "Gig Economy,"” 195.

${ }^{73}$ Disaggregated country figures are unavailable, but Deloitte has estimated the percentage of millennials globally by 2025 will be 75 per cent. See Deloitte, Big Demands and High Expectations.

${ }^{74}$ Urbis, National Profile, 9.
} 
about work ethic and do we think they're going to be able to pick up the work and how are they going to be with clients, rather than just how they look on paper ... some people do have fairly strong opinions about schools and unis and those sorts of things, but that's where I come in, in my role, to challenge those things [HR Manager, Aus., Female, 18 April 2018].

Despite the ostensible preference for surface-level diversity in appointments, it has nevertheless been suggested there is a desire by most organisations for deep-level cultural homogeneity. ${ }^{75}$ Hilary Sommerlad made this point forcefully in her analysis of legal professionalism in England and Wales in the last 20 years. ${ }^{76}$ The neoliberal turn with its passion for profit maximisation has induced the profession to slough off any obligation to young lawyers, relegating them to an uncertain future. This has contributed to their pronounced levels of stress, anxiety and mental ill health. ${ }^{77}$ While cultural homogeneity in respect of gender, sexuality and class is disrupted by the anonymity of online contractualism, it conveniently obscures the growing discrimination against young lawyers.

\section{Conclusion}

NewLaw maximises the freedom, independence and autonomy of lawyers, provided they are at a reasonably senior level. While contractors can choose to work as little as 10 hours per week, principals are constrained by targets and budgets to generate revenues, pay overheads, and still make a profit:

For the first year that [X Firm] existed, I tried very, very hard not to have any bureaucracy, no kind of formal meetings, policies, procedures, anything like that, no KPIs [key performance indicators], no targets, whether they were financial targets or not. And then I realised that it's actually very hard to track performance if you don't have them. And on the other side of the equation is that quite a few of our managers actually asked for targets [Manager, Aus., Male, 5 April 2018].

While NewLaw may presently be generating a comparatively small share of legal services revenue, ${ }^{78}$ it is undoubtedly disrupting the established norms of legal practice in accordance with Clayton Christensen's thesis. ${ }^{79}$ However, at this stage, 'disruption' does not appear to be displacing the large corporate firms altogether, which remain highly profitable.$^{80}$ The exodus of senior lawyers from elite firms who take their clients with them must nevertheless be giving those firms pause, and the marked success of some NewLaw firms is likely to encourage more senior lawyers to take the plunge:

It's a little bit about having the confidence to exit what they're doing cos ... you're comfortable and you get an annual wage and it's a bit risky to go out on your own - but the more of these virtual firms like us ... who offer the freelancing to employees - the more of that that comes out, the more women are gonna feel confident to leave and start their own thing and they'll have some workflow [Director, Aus., Female, 3 March 2018].

I think it's becoming a very attractive way of working if you know that you can-I think the risk in the past has been-is it viable, will I continue to get assignments, or am I going to get a three-month assignment and then be unemployed for six months? So, only really attracted people who could afford not to work continuously and that's why I think juniors will find it very difficult to work in this way. But as the needs continue to increase, I think it will become very attractive to lawyers. And from the point of view of the clients, it's a great way of filling gaps of skill set, peak workloads, not having to go without during a period of extended leave [Manager, Aus., Female, 22 March 2018].

Despite the new ways of practising law, as with the gig economy, ${ }^{81}$ the individualism and ageism associated with NewLaw have not been confronted. While the idea of the gig economy has a superficial appeal for young people - the "digital natives ${ }^{82}$ their futures are uncertain. Firms are less than enthusiastic about appointing recent graduates to permanent jobs, a situation that favours gigging ${ }^{83}$ which is still largely confined to the lower end of the labour market. While gigging could act as a stepping stone to more secure work, it may prove a trap for the unwary from which it is difficult to extricate oneself. ${ }^{84}$

\footnotetext{
${ }^{75}$ Rivera, Pedigree.

${ }^{76}$ Sommerlad, "The New 'Professionalism."”

77 Collier, "Anxiety and Wellbeing Amongst Junior Lawyers"; Junior Lawyers Division, Resilience and Wellbeing Survey 2019.

${ }^{78}$ Despite the considerable attention that gig economy players such as Uber have attracted, its actual effect on the economy in both the US and Australia is reported to be minuscule. See Healy, "Should We Take the Gig Economy Seriously?", 233.

${ }^{79}$ Christensen, The Innovator's Dilemma.

${ }^{80}$ Pitcher Partners. "Legal Firm Survey"; Waye, "Innovation," 5.

${ }^{81}$ Webster, "Microworkers of the Gig Economy," 62.

82 Palfrey, Born Digital; Doraisamy, "Why New Lawyers are Particularly Suited to New Law."

${ }^{83}$ Consult Healy, "Should We Take the Gig Economy Seriously?", 238.

${ }^{84}$ Consult Healy, "Should We Take the Gig Economy Seriously?", 240.
} 
The less experienced end of the market is also vulnerable to rapid developments in AI. If jobs disappear, it is more likely those performed by junior lawyers and paralegals ${ }^{85}$ — that is, those already deleteriously affected by technological innovation in legal practice. The risk of junior lawyers being unemployed, under-employed or unsupervised leaves a large question mark over their future. The bottleneck at the point of graduation is contributing to a growing precariat ${ }^{86}$ that NewLaw is doing little to alleviate. Further, while the gig economy is presently confined to the lower end of the legal market, it is presently inching its way upstream, threatening to change irrevocably the nature of legal professionalism.

\section{Bibliography}

Adams, Abi, Judith Freedman and Jeremias Prassi. "Rethinking Legal Taxonomies for the Gig Economy." Oxford Review of Economic Policy 34, no 3 (2018): 475-94.

Arendt, Hannah. The Human Condition. Chicago: University of Chicago Press, 1958.

Bagust, Joanne. "The Legal Profession and the Business of Law." Sydney Law Review 35 (2014): $27-52$.

—. "The Culture of Bullying in Australian Corporate Law Firms." Legal Ethics 17, no 2 (2014): 177-201. https://doi.org/10.5235/1460728X.17.2.177.

Baron, Paula. "The Elephant in the Room? Lawyer Wellbeing and the Impact of Unethical Behaviours." Australian Feminist Law Journal 41, no 1 (2015): 87-119. https://doi.org/10.1080/13200968.2015.1035209

Bauman, Zygmunt. Liquid Modernity. Cambridge: Polity, 2000.

Barzilay, Arianne Renan and Anat Ben-David. "Platform Inequality: Gender in the Gig-Economy." Seton Hall Law Review 47, no 2 (2017): 393-431.

Bergin, Adele J. and Nerina Jimmieson. "Australian Lawyer Well-Being: Workplace Demands, Resources and the Impact of Time-Billing Targets.” Psychiatry, Psychology and Law 21, no 3 (2014): 427-41. https://doi.org/10.1080/13218719.2013.822783

Billett, Nicole. "The Gig Lawyer in the Gig Economy." Lawyers Weekly, 8 December 2017. https://www.lawyersweekly.com.au/sme-law/22395-the-gig-lawyer-in-the-gig-economy.

Bolton, Sharon C. and Daniel Muzio. “Can't Live with 'Em; Can't Live without 'Em: Gendered Segmentation in the Legal Profession.” Sociology 41, no 1 (2007): 47-64. https://doi.org/10.1177\%2F0038038507072283

Caserta, Salvadore and Mikael Rask Madsen. "The Legal Profession in the Era of Digital Capitalism: Disruption or New Dawn?” Laws 8, no 1 (2019). https://doi.org/10.3390/laws8010001

Chan, Janet, Suzanne Poynton and Jasmine Bruce. "Lawyering Stress and Work Culture: An Australian Study." University of New South Wales Law Journal 37, no 3 (2014): 1062-102.

Christensen, Clayton M. The Innovator's Dilemma: The Revolutionary Book That Will Change the Way You Do Business, rev. ed. New York: Collins Business Essentials, 2003.

Christensen, Clayton M., Taddy Hall, Karen Dillon and David Duncan. Competing Against Lack: The Story of Innovation and Custom Choice. New York: Harper Business, 2016.

Collier, Richard. "Anxiety and Wellbeing Amongst Junior Lawyers: A Research Study." Presentation at Mind your Head, Anxiety, London, UK, June 2019.

"Wellbeing in the Legal Profession: Reflections on Recent Developments (Or, What Do We Talk about When We Talk about Wellbeing?” International Journal of the Legal Professions 23, no 1 (2016): 41-60. http://dx.doi.org/10.1080/09695958.2015.1113970

“ 'Love Law, Love Life': Neoliberalism, Wellbeing and Gender in the Legal Profession-The Case of Law School.” Legal Ethics 17, no 2 (2014): 202-30.

Cooke, Darryl. “A New Future for the Law.” Modern Legal Practice 2, no 1 (2018): 15-9.

Council of Australian Law Deans. "Data Regarding Law School Graduate Numbers and Outcomes.” 2015. https://cald.asn.au/wp-content/uploads/2017/11/Factsheet-Law_Students_in_Australia.pdf

Davies, William. The Happiness Industry: How the Government and Big Business Sold Us Well-Being. London: Verso, 2015.

Deloitte. Big Demands and High Expectations: The Deloitte Millennial Survey. London: Deloitte, 2014.

https://www2.deloitte.com/content/dam/Deloitte/global/Documents/About-Deloitte/gx-dttl-2014-millennial-surveyreport.pdf

\footnotetext{
${ }^{85}$ Consult Waye, "Innovation," 10.

${ }^{86}$ Sommerlad, "The New 'Professionalism."”
} 
Doraisamy, Jerome. "Why New Lawyers are Particularly Suited to New Law.” Lawyers Weekly, 23 July, 2018. https://www.lawyersweekly.com.au/newlaw/23678-why-new-lawyers-are-particularly-suited-to-newlaw

Golden, Lonnie, Julia R. Henley and Susan Lambert. "Work Schedule Flexibility: A Contributor to Happiness?” Journal of Social Research \& Policy 4 (2013): 107-35.

Graceffa, Sandrino and Sarah de Heusch. "Reinventing the World of Work.” Transfer 23, no 3 (2017): 359-65.

Grech, Andrew and Kirsten Morrison. "Slater \& Gordon, The Listing Experience." Georgetown Journal of Legal Ethics 22 (2009): 535-40.

Gregg, Melissa. Work's Intimacy. Cambridge: Polity, 2011.

Hardt, Michael and Antonio Negri. Commonwealth. Cambridge, MA: Harvard University Press, 2009.

Harvey, David. The Condition of Postmodernity: An Enquiry into the Origins of Cultural Change. Oxford: Blackwell, 1990.

Healy, Joshua, Daniel Nicholson and Andreas Pekarek. "Should We Take the Gig Economy Seriously?" Labour \& Industry: A Journal of the Social and Economic Relations of Work 27, no 3 (2017): 232-48. https://doi.org/10.1080/10301763.2017.1377048

Hong, Emily. "Making it Work: A Closer Look at the Gig Economy.” New American Weekly, edn. 94, 1 October, 2015. https://www.newamerica.org/weekly/94/making-it-work-a-closer-look-at-the-gig-economy/.

Jacobowitz, Jan L., Katie M. Lachter and Gabriella Morello. "Cultural Evolution or Revolution? The Millennial's Growing Impact on Professionalism and the Practice of Law." The Professional Lawyer 23, no 4 (2016): $20-34$.

Josef, "Interview with Eric Chin, the Man Who Coined the Phrase 'NewLaw"” (blog). n.d. https://joseflegal.com/blog/interview-with-eric-chin-the-man-who-coined-the-phrase-newlaw

Junior Lawyers Division. Resilience and Wellbeing Survey 2019. (London: The Law Society, 2019). http://communities.lawsociety.org.uk/Uploads/b/y/k/resilience-wellbeing-survey-report-2019.pdf

Katz, Daniel Martin. "Quantitative Legal Prediction—or-How I Learned to Stop Worrying and Start Preparing for the DataDriven Future of the Legal Services Industry." Emory Law Journal 62, no 4 (2013): 909-66.

Kaufmann, Sue and Georgina Frost. Flexible Partnership: Making it Work in Law Firms. Melbourne: Victorian Women Lawyers, 2002.

Kay, Fiona M., Stacey L. Alarie and Jones K. Adjei. "Leaving Private Practice: How Organizational Context, Time Pressures, and Structural Inflexibilities Shape Departures from Private Law Practice”. Indiana Journal of Global Legal Studies 20, no 2 (2013): 1223-60.

King, Andrew A. and Baljir Baatartogtokh. "How Useful is the Theory of Disruptive Innovation?" MIT Sloan Management Review. September 15 2015. https://sloanreview.mit.edu/article/how-useful-is-the-theory-of-disruptive-innovation/.

Law Council of Australia. The Justice Project: Final Report. Canberra: Law Council of Australia, 2018. https://www.lawcouncil.asn.au/justice-project/final-report

- National Attrition and Re-Engagement Study (NARS). Canberra: Law Council of Australia, 2014.

Le Mire, Suzanne and Rosemary Owens. "CA Propitious Moment? Workplace Bullying and Regulation of the Legal Profession". University of New South Wales Law Journal 37, no 3 (2014): 1030-61.

Lepore, Jill. "The Disruption Machine: What the Gospel of Innovation Gets Wrong." The New Yorker, 16 June 2014. https://www.newyorker.com/magazine/2014/06/23/the-disruption-machine

Mahlab Recruitment. "Mahlab Report 2018.” 2018. http://www.mahlab.com.au/report18-corporate.pdf

Mark, Steve and Tahlia Gordon. "Innovations in Regulation: Responding to a Changing Legal Services Market." Georgetown Journal of Legal Ethics 22 (2009): 501-33.

Mavenlink. "The White-Collar Gig Economy." 2017. http://go.mavenlink.com/hubfs/Downloadable_Content/Ebooks_And White_Papers/white-collar-gig-economy-ondemand-trends-oct-2017.pdf?submissionGuid=0dfe4d54-0081-4268-9407-db4d64312999, accessed 30 July 2019.

NSW Law Society. “Annual Profile, 2015.” https://www.lawsociety.com.au/advocacy-and-resources/advancement-ofwomen/gender-statistics

NSW Young Lawyers and Australian National University. "Being Well in the Law: A Guide for Lawyers." Sydney: Law Society of NSW, 2016.

Nurvala, Juha-Pekka. “'Uberisation' is the Future of the Digitalised Labour Market.” European View 14, no 2 (2015): 231-9. https://doi.org/10.1007/s12290-015-0378-y.

Omari, Maryam and Megan Paull. "Shut up and Bill': Workplace Bullying Challenges for the Legal Profession." International Journal of the Legal Profession 20, no 2 (2013): 141-60. https://doi.org/10.1080/09695958.2013.874350 
Palfrey, John and Urs Gasser. Born Digital: Understanding the First Generation of Digital Natives. New York: Basic Books, 2008.

Parker, Christine. "Converting the Lawyers: The Dynamics of Competition and Accountability Reform." Australia and New Zealand Journal of Sociology 33, no 1 (1997): 39-55.

Pitcher Partners. "Legal Firm Survey.” 2017. http://www.pitcher.com.au/sites/default/files/downloads/2017\%20Legal\%20Survey\%20Report\%20.pdf.

Rated Solicitors.com. 2013. http://www.ratedsolicitors.com/

Reiter, Natalie. "Work Life Balance: What DO You Mean? The Ethical Ideology Underpinning Appropriate Application." Journal of Applied Behavioural Science 43 (2007): 273-94. https://doi.org/10.1177\%2F0021886306295639

Rivera, Lauren A. Pedigree: How Elite Students Get Elite Jobs. Princeton: Princeton University Press, 2015.

Rosenblat, Alex. Uberland: How Algorithms Are Rewriting the Rules of Work. Oakland: University of California Press, 2018.

Ryan, Emma. “College of Law Boss Opens up about Today's Law School Paradigm.” Lawyers Weekly, 15 April, 2019. https://www.lawyersweekly.com.au/careers/25455-college-of-law-boss-opens-up-about-today-s-law-schoolparadigm.

Sommerlad, Hilary. “The New 'Professionalism' in England and Wales: Talent, Diversity, and a Legal Precariat.” In Diversity in Practice: Race, Gender, and Class in Legal and Professional Careers, edited by Spencer Headworth, Robert L. Nelson, Ronit Dinovitzer and David B. Wilkins, 236-60. Cambridge: Cambridge University Press, 2016.

Susskind, Richard. Tomorrow's Lawyers: An Introduction to Your Future. Oxford: Oxford University Press, 2013.

Thornton, Margaret. "Work/Life or Work/Work: Corporate Legal Practice in the Twenty-First Century." International Journal of the Legal Profession 23. no 1 (2016): 13-39. https://doi.org/10.1080/09695958.2015.1093939

. "The Flexible Cyborg: Work-Life Balance in Legal Practice." Sydney Law Review 38, no 1 (2016) 1-21.

. "Squeezing the Life out of Lawyers: Legal Practice in the Market Embrace." Griffith Law Review 25, no 4: 471-91. https://doi.org/10.1080/10383441.2016.1262230

. "Hypercompetitiveness or a Balanced Life? Gendered Discourses in the Globalisation of Australian Law Firms." Legal Ethics 17, no 2 (2014): 153-76. https://doi.org/10.5235/1460728X.17.2.153

Todoli-Signes, Adrián. “The 'Gig Economy': Employee, Self-Employed or the Need for a Special Employment Regulation?” Transfer 23, no 2 (2017): 193-205. https://doi.org/10.1177\%2F1024258917701381

Urbis Pty Ltd. National Profile of Solicitors 2016. Report prepared for the Law Society of NSW. Urbis, 2017. https://www.lawsociety.com.au/sites/default/files/201804/NATIONAL\%20PROFILE\%20OF\%20SOLICITORS\%202016.compressed.pdf

Victorian Women Lawyers. A $360^{\circ}$ Review: Flexible Work Practices: Confronting Myths and Realities in the Legal Profession Firms. Melbourne: Victorian Women Lawyers, 2002.

Waye, Vicki, Martie-Louise Verreyne and Jane Knowler. "Innovation in the Australian Legal Profession.” International Journal of the Legal Profession 25, no 2 (2017): 213-41. https://doi.org/10.1080/09695958.2017.1359614

Webster, Juliet. "Microworkers of the Gig Economy: Separate and Precarious.” New Labor Forum 25, no 3 (2016): 56. https://doi.org/10.1177\%2F1095796016661511

Williams, Joan. Unbending Gender: Why Family and Work Conflict and What to Do about It. Oxford: Oxford University Press, 2000.

Williams, Joan C., M. Blair-Loy and J. L. Berdahl. "Cultural Schemas, Social Class, and the Flexibility Stigma.” Journal of Social Issues 69, no 2 (2013): 209-34. https://psycnet.apa.org/doi/10.1111/josi.12012

Williams, Joan C., Aaron Platt and Jessica Lee. "Disruptive Innovation: New Models of Legal Practice." Legal Studies Research Paper Series No. 142. Hastings: University of California Hasting College of Law, 2015. http://www.uchastings.edu/news/articles/2015/06/Disruptive-Innovation-New-Models-of-Legal-Practice.pdf

\section{Primary Legal Material}

International

Workers with Family Responsibilities Convention, 23 June 1981, International Labour Organization No. 156 (entered into force 11 August 1983).

Australia

Age Discrimination Act 2004 (Cth).

Competition Policy Reform Act 1995 (Cth). 
Independent Committee of Inquiry into Competition Policy in Australia. Canberra: Australian Government Publishing Service, 1993.

\section{United Kingdom}

Equality Act 2010.

Legal Services Act 2000. 